\title{
Korku Kültürü Çerçevesinde Medyada Korku Söylemi: Bir Örnek Olarak 31 Ekim 2016 Cumhuriyet Gazetesi Operasyonu
}

\author{
Ahmet Cevdet Așkın \\ doktora öğrencisi, galatasaray üniversitesi, medya ve iletişim çalışmaları \\ cevdetaskin@yahoo.com
}

\begin{abstract}
The Discourse of Fear in Relation to the Culture of Fear through the Media: The Case of the Daily Cumhuriyet on October, 31, 2016

This article aims to draw attention to the fact that the culture of fear as a result of the discourse of fear reproduced by the media in Turkey has become a political instrument of repression. This discourse is established on the base of terrorism, especially by putting quite different organizations in the same basket, as if they are identical. In the paper, it is tried to reveal the building of the said discourse in the published news stories about the detention operation at the daily Cumhuriyet on October, 31, 2016 by using critical discourse analysis. For this, the news about the event on the first pages of the turkish dailies Sabah, Takvim, Star, Yeni Şafak, Türkiye, Yeni Akit, Akşam, Güneş, Milliyet, Vatan, Habertürk, Yeni Asya, Yeni Birlik and Hürriyet published on November, 1, 2016, have been analysed according to the discourse-historical approach conceptualised essentially by Ruth Wodak. As a result, it is found that the discourse of fear is established on the identification of Cumhuriyet with organizations such as FETÖ, PKK and PYD.
\end{abstract}

keywords: discourse of fear, culture of fear, politics of fear, daily Cumhuriyet, critical discourse analysis, discourse-historical approach

Bu makaleye referans vermek için: Aşsın, C. A., (2017). Korku Kültürü Çerçevesinde Medyada Korku Söylemi: Bir Örnek Olarak 31 Ekim 2016 Cumhuriyet Gazetesi Operasyonu. Galatasaray Üniversitesi Illeti-ş-im Dergisi, 27, 109-134. 


\section{Résumé}

\section{Le discours de la peur en relation avec la culture de la peur dans les médias: le cas du quotidien Cumhuriyet daté le 31 octobre 2016}

L'objectif de cet article est d'attirer l'attention sur le fait que la culture de la peur est devenue un outil de répression politique suite aux discours de la peur produits et reproduits par l'intermédiaire des médias en Turquie. La base essentielle de ce discours s'appuie sur le terrorisme, corrèle les différentes organisations, et va parfois même jusqu'à identifier les unes avec les autres. II a été question de démontrer dans cette étude, la façon dont le dit discours a été construit dans les informations sur l'opération du 31 octobre 2016 contre Cumhuriyet. Durant l'analyse des articles sur l'opération publiés en première page des quotidiens Sabah, Takvim, Star, Yeni Şafak, Türkiye, Yeni Akit, Akşam, Güneş, Milliyet, Vatan, Habertürk, Yeni Asya, Yeni Birlik et Hürriyet le $1^{e r}$ novembre 2016, I'approche historique du discours développé par Ruth Wodak a été utilisée. A la suite de l'analyse critique du discours, il semblerait que le discours de la peur est construit sur le fait que le quotidien Cumhuriyet est associé à des organisations telles que le FETÖ, le PKK et le PYD.

mots-clés : discours de la peur, culture de la peur, politique de la peur, quotidien Cumhuriyet, analyse critique du discours, approche historique du discours

\section{Öz}

Bu makalenin amacı Türkiye'de medya aracılığıyla üretilen ve yeniden üretilen korku söyleminin sonucu olan korku kültürünün bir siyasal baskı aracı haline geldiğine dikkat çekmektir. Temel taşını terörizmin oluşturduğu bu söylem, birbirinden farklı örgütlerin birbirleriyle ilintilendirilmesi ve bazen de özdeşleştirilmesiyle kurulmaktadır. Çalışmada Cumhuriyet gazetesine dönük 31 Ekim 2016'da başlayan operasyon ile ilgili çıkan haberlerde söz konusu söylemin nasıl inşa edildiği eleştirel söylem analizinden yararlanılarak ortaya çıkarılmaya çalışıImıştır. 1 Kasım 2016 tarihinde yayımlanan Sabah, Takvim, Star, Yeni Şafak, Türkiye, Yeni Akit, Akşam, Güneş, Milliyet, Vatan, Habertürk, Yeni Asya, Yeni Birlik ve Hürriyet gazetelerinin birinci sayfalarında operasyonla ilgili yer alan haberler analiz edilirken Ruth Wodak'ın geliştirdiği söylem-tarihsel yaklaşımdan yararlanılmıştır. Yapılan analizler sonucunda korku söyleminin Cumhuriyet gazetesinin FETÖ, PKK ve PYD gibi örgütlerle özdeşleştirilmesi üzerine kurulduğu ortaya çıkmıştır.

anahtar kelimeler: korku söylemi, korku kültürü, korku politikası, Cumhuriyet gazetesi, eleştirel söylem analizi, söylem-tarihsel yaklaşım 


\section{Giriş}

Günümüz dünyasında insanların yaşamına risk, tehlike ve güvenlik kavramlarının damga vurduğu, ağırlıklı olarak medyanın bu kavramlar üzerinden yürüttüğü faaliyeti sonucunda bir korku kültürünün oluştuğu gözlemlenmektedir. Kuşkusuz ekolojik, ekonomik, siyasal ve askeri planda küresel kapitalizmin sonucu olarak risk ve tehlikelerde bir artışın söz konusu olduğundan söz edilebilir. Bu durumun güvenlik kaygılarında artışa yol açması da doğaldır. Ancak risk ve tehlikelere yaklaşım yöntemine bağlı olarak oluşan/oluşturulan korku kültürünün, insanları teslim alması ve onları kaderlerine razı, edilgen bireylere dönüştürmesinin, diğer bir ifadeyle içi boşaltılan özneler düzeyine indirgemesinin hâkim küresel kapitalist sistemin çıkarına olduğu ileri sürülebilir.

Bu makalede medyanın ürettiği korku söyleminin bir sonucu olan korku kültürünün muhalefetin baskılanmasında ve susturulmasında siyasal bir araca dönüşmesi, Cumhuriyet'e yapılan operasyon bağlamında gösterilmeye çalışımaktadır. Söz konusu olan siyasal araç, korku politikasıdır ve bu politikanın yurttaşları teslim alarak edilgen ve kaderlerine razı bireyler haline dönüştürmesinde medya kritik bir rol oynamaktadır.

Çalışmada medya aracılığıyla korku söylemi ve dolayısıyla korku kültürünün üretilmesiyle ilgili kuramsal çerçeve, Furedi ile Altheide'in düşünce hattı üzerinden oluşturulmaya çalışılmakta ve Althusser'in devletin ideolojik aygıtları kavramı temelinde medyanın korku kültürünün oluşturulmasındaki işlevi değerlendirilmektedir. Ardından Gramsci'yi izleyerek medyanın bu çerçevedeki rolünün hegemonya inşasına olan etkisine değinilmektedir. Bu şekilde kurulan kuramsal çerçeveden son dönemde Türkiye'de basında hâkim olan korku söylemine bakılmaktadır. Temel taşını terörizmin oluşturduğu bu söylemin, birbirinden farklı örgütlerin birbirleriyle ilintilendirilerek ve kimi zaman da özdeşleştirilerek kuruluşuna dikkat çekildikten sonra ülkenin en eski basın kuruluşlarından Cumhuriyet gazetesine dönük 31 Ekim 2016'da başlayan operasyonla ilgili çıkan haberlerde söz konusu söylemin somutlanışı araştırımaktadır. Basında bu çerçevede oluşturulan korku söyleminin şifrelerinin çözülmesinde esas olarak eleştirel söylem analizi (ESA) çerçevesinde Ruth Wodak'ın geliştirdiği söylem-tarihsel yaklaşımdan (STY) yararlanılmaktadır.

\section{Cumhuriyet Operasyonunun Siyasal ve Sektörel Bağlamı}

31 Ekim 2016 tarihinde Cumhuriyet gazetesi çalışanlarına dönük gözaltı operasyonunu ve ardından tutuklanmalarını, siyasal iktidarın medya üzerindeki ağır baskısının bir tezahürü olarak değerlendirmek yerinde olacaktır. Söz konusu bağlamın anlaşılması için öncelikle Türkiye'deki medya sisteminin günümüzdeki durumuna panoramik olarak bakılması kaçınılmaz bir zorunluluktur. 
Aslında 24 Ocak 1980'de uygulamaya konulan ekonomik tedbirlerin Türkiye'yi ekonomiden siyasete yeniden düzenlemesinin bir sonucu olarak yaşanan 2001 krizi, günümüzdeki medya tablosunu şekillendiren gelişmelerin başlangıç noktası olarak alınabilir. Kriz bir yandan Adalet ve Kalkınma Partisi'ni (AKP) 2002 seçimlerinde güçlü bir şekilde iktidara taşırken, diğer yandan da 1980 'lerden itibaren uygulanan neo-liberal ekonomi politikalarının bir sonucu olarak aile şirketlerinden holdinglerin hâkim olduğu bir sisteme dönüşmüş olan medyada (Adaklı, 2006; Kaya, 2009; Aydın, 2015) önemli değişimlere yol açmıştır. 2001 krizinin medya sektöründeki iki önemli sonucu söyle olmuştur (Kurban ve Sözeri, 2012, s. 89):

\begin{abstract}
Birincisi, devlet TMSF aracılığıyla pek çok medya kuruluşunun sahibi haline gelmiştir. Íkincisi, el konan bu medya kuruluşlarının bir kısmı, daha önce medya sektöründe yatırımı bulunmayan ancak AKP hükümetine yakın olan sermayedarlara, üstelik devlet bankaları yoluyla kredi sağlanarak satılmıştır. Bu yeniden yapılanmanın sonucu olarak medyada güç, daha evvel ideolojik olarak orduya yakın ve hükümete muhalif gruplardan hükümete yakın sermayedarlara geçmiştir.
\end{abstract}

AKP hükümeti medya sermayesindeki bu değişim temelinde sektörde tam hâkimiyetini kurmuştur. Ilımlı muhalefet yapan Doğan Grubu vergi cezası baskısı altında küçülmeye zorlanmıştır. Star TV nin yanı sıra Milliyet ve Vatan gazeteleri de satılmıştır. Grubun Hürriyet, Radikal ve Posta gazeteleri ile Kanal D ve CNN Türk televizyon kanalları özellikle hükümete karşı düzenlenen 17- 25 Aralık 2013 operasyonlarının ardından ılımlı muhalif görünümünü de yitirip "nötr" yayıncııı yapmaya başlamıştır. Bu arada Radikal gazetesinin önce kâğıt baskısına sonra da dijital yayınına son verilerek yayın hayatına nokta konulmuştur. Bu dönemde hükümetin çeşitli kanallarla basın ve yayın politikalarını kontrol altına almasının yanı sıra artan baskı karşısında medya mensuplarında "oto sansür" de gelişmiştir. Böylece hükümetin göstereceği tepki, haberlerin hazırlanmasında gözetilecek temel kıstas haline gelmiştir.

15 Temmuz başarısız darbe girişiminin ardından iktidarın Fethullahçı Terör Örgütü (FETÖ) gerekçesiyle tüm muhalif sesleri susturma politikası devreye girmiştir. Illan edilen Olağanüstü Hal $(\mathrm{OHAL})$, imkân verdiği kanun hükmünde kararname uygulaması ile anti-demokratik bir baskı rejimi halini almıştır.

Çağdaş Gazeteciler Derneği Ankara Şubesi tarafından hazırlanan Temmuz Eylül dönemi üç aylık medya raporuna göre 15 Temmuz sonrası ilan edilen OHAL sürecinde 118 basın kuruluşu kapatılmış, 184 basın emekçisi gözaltına alınmış ve bunlardan 56'sı tutuklanmıştır. Aynı süreçte 886 basın emekçisi işsiz kalmış, 620 gazetecinin basın kartı, 32'sinin de parlamento kartı iptal edilmiştir (ÇGD, 2016).

Avrupa Komisyonu tarafından 9 Kasım'da yayımlanan ilerleme raporunda da ifade özgürlüğü başlığı altında Türkiye'de devletin medyaya müdahalesine ilişkin şu tespitler yer almıştır (2016, s. 72): 
15 Temmuz'dan sonra yüksek sayıda gazetecinin tutuklanması ciddi bir kaygı oluşturmaktadır. (...) Medya gruplarına hükümetin el koyması devam etmektedir. Çok sayıda gazeteci işten çıkarılırken bu kurumlara atanan kayyumlar yayın politikasını değiştirmektedir. Darbe girişiminin ardından hükümet, öncelikli olarak Gülen hareketiyle ilişkili olduğu iddia edilen radyo ve televizyon kanallarının kapatılmasını sağlayan kanun hükmünde kararnameler yayınladı. Bununla birlikte kapatmalar ve faaliyetlerin askıya alınması, Kürtçe yayın yapan bir dizi kanalın yanı sıra bir Alevi kanalını ve bazı muhalif kanalları da kapsadı. Ekim sonu itibariyle 46 televizyon ve radyo kanalı, 5 haber ajansı, 55 gazete ve 18 dergi kapatıldı, yaklaşık 90 gazeteci hakkında gözaltı kararı çıkarıldı, 20'den fazla internet sitesine erişim engellendi ve 29 yayınevinin faaliyetlerine son verildi.

Cumhuriyet gazetesine 31 Ekim 2016 tarihinde yapılan operasyon böylesi bir siyasal konjonktürde gerçekleştirilmiştir. Operasyon çerçevesinde 18 kişi hakkında gözaltı kararı çıkarılmış ve sonunda gazetenin genel yayın yönetmeni, yazar ve vakıf yöneticileri de dâhil olmak üzere toplam 10 kişi tutuklanmıştır.

\section{Kuramsal Çerçeve: Korku Söylemi, Korku Kültürü ve Medyanın Rolü}

Alman sosyolog Ulrich Beck tarafından 90'lı yılların başında Risk Society: Towards a New Modernity eseriyle ortaya atılan risk toplumu kavramı, yazarın aynı çizgide daha sonraki çalışmalarının da etkisiyle akademik dünyada tartışmalara yol açmıştır.

Geçmişten farkla günümüz toplumunda riskler "üretilmiş" risklerdir ve çoğunlukla alınan kararlara bağlı olarak oluşmaktadır. O nedenle riskler denetlenemez ve kontrol altına alınamaz türdendir. Bu durum bir belirsizlik haline yol açmaktadır (Beck,1992). Keza ünlü İngiliz sosyolog Anthony Giddens da Beck'e paralel şekilde bilginin artması ile risk algısı arasında doğrudan bir ilişki kurmaktadır (Beck vd., 1994).

Macar asıllı sosyolog Frank Furedi ise günümüz toplumuna yaklaşımda Beck'e karşıt konumda yer almaktadır. Korku Kültürü (2014) kitabında risk ve tehlikeler konusunun abartıldığını, bu konuda medyanın etkin bir işlev gördüğünü ve bunun sonucunda bir korku kültürünün oluştuğunu ileri sürmektedir. Ona göre bu kültür özneye verilen önemin azalması demektir. Bunun altında da mevcut durumun değiştirilmesine dönük olarak insan müdahalesinin etkisiz olduğu görüşü yatmaktadır.

Söylemin dille inşa edildiği, dil aracılığıyla duygu ve düşüncelerimizin ifade edildiği ve buna göre hareket edildiği göz önüne alındığında, toplumda hâkim söylemin nasıl ve kimler tarafından kurulduğu önem arz etmektedir. Çünkü korku kültürü, korku söylemi üzerinden üretilmekte ve bu üretim sürecinde medya başat rol oynamaktadır. 
Korku söylemi, tehlike ve riskin insanların gündelik yaşamlarında deneyimledikleri fiili çevrenin temel bir özelliği haline gelmesini sağlayan yaygın iletişim, sembolik farkındalık ve beklenti olarak tarif edilebilir (Altheide ve Michalowski, 1999, s. 476). Altheide, Mass Media, Crime and The Discourse of Fear makalesinde korku söyleminin en büyük etkisinin bir kargaşa duygusunu ve işlerin kontrolden çıktığı inancını körüklemesi olduğundan söz etmektedir (2003, s. 19). Bu durumun sonucunda yönetimlerin sivil özgürlükleri kısıtlaması ya da askıya alması kolaylaşmaktadır. Yani korku söylemi temelinde politika yürütülmesi söz konusudur. Altheide, Terrorism and the Politics of Fear makalesinde günümüz toplumları için son derece kritik hale gelen korku politikasıyla ilgili şunları söylemektedir (2006, s. 423):

\begin{abstract}
Korku politikası korku söylemine dayanır. Korku politikası, iktidar, propaganda, haberler ve popüler kültür için kavramsal bir bağ olarak işlev görür. Korku politikası, bir liderin doğrudan tehditlerine değil, ama toplumsal yaşamı tehlikeli, korkulu ve fiili ya da potansiyel kurbanlarla dolu olarak karakterize eden kamusal söyleme dayanır. Bu sembolik düzen daha fazla kurban konumuna düşmeyi engellemek için önlemlere, polisin devreye girmesine ve müdahaleye davetiye çıkarır. Korku söylemi korku politikasını davet eder. Toplumsal yaşamda korkunun kendisi değil, daha ziyade korkunun nasıl tarif edildiği ve toplumun günlük yaşamında nasıl somutlaştığı önemlidir. Haber medyası, seçilmiş haber kaynaklarının mesajlarının aktarılmasında büyük rol oynar.
\end{abstract}

Medyanın, korku politikasına dayanak sağlayan korku söyleminin inşasında sözü edilen önemli rolü nereden kaynaklanmaktadır? Medya kamusal yaşamda zaten var olan korkuyu basit bir ayna gibi yansıtmakta mıdır? Yoksa haberlerin yapılmasında, neyin haber olacağına karar verilmesinde, haberlere temel teşkil eden kaynakların seçiminde aktif olarak korku söyleminin üretilmesinde işlev görecek şekilde mi hareket etmektedir? Bu soruların yanıtının aranması medyanın ekonomik ve siyasal sistem içinde işgal ettiği yerin sorgulanmasını zorunlu kılmaktadır.

Ünlü Fransız felsefeci Louis Althusser, çığır açan makalesi Idéologie et appareils idéologiques d'État'da kapitalist sistemin yeniden üretilmesini garantileyen devletin baskı aygıtları ile ideolojik aygıtlarından söz etmektedir. Baskı aygıtlarının ordu, polis, mahkemeler ve hapishane gibi kurumlardan oluştuğunu belirten Althusser, ideolojik aygıtlar olarak aile, din ve eğitimin yanı sıra enformasyonu (basın, radyo-tv, vb.) yani medyayı da saymaktadır (Althusser, 1976). Bu çerçeveden bakıldığında medyanın izlediği yayın politikasıyla, kurulu düzenin sürdürülmesinde ve yeniden üretilmesinde önemli bir ideolojik işlev gördüğ̈ söylenebilir.

Öte yandan iletişime ekonomi politik yaklaşımla bakıldığında medyanın sermaye yapısı, Althusser'in medyayı ideolojik aygıtlar çerçevesinde değerlendirmesini desteklemektedir. Örneğin Edward Herman ile birlikte 
Propaganda Modeli'ni geliştiren Noam Chomsky'ye göre medya "haberlerin ve çözümlemelerin çatısını yerleşik ayrıcalıkları destekleyen bir çerçevede kurarak ve bu doğrultuda her türlü tartışmayı sınırlayarak birbiriyle sıkı sıkıya kaynamış olan devletin ve şirketlerin çıkarlarına hizmet eder" (2012, s. 16). Bu çerçevede medyanın sermaye yapısının sonucu olarak devletin ideolojik aygıtı işlevini gördügü ileri sürülebilir.

Medyanın devletin ideolojik aygıtı olarak işlev görmesinin mevcut statükonun sürdürülmesinde muktedirlerin hegemonyasının gün be gün inşasına katkı yapacağı da açıktır. Martin Carnoy, Gramsci'nin geliştirdiği hegemonya kavramının iki anlamına dikkat çekmektedir. Bunlardan birincisi, sivil toplumda egemen sınıfın bir fraksiyonunun ahlaki ve entelektüel liderliği yoluyla egemen sınıfın öbür müttefik fraksiyonları üzerinde denetim uyguladığı bir sürece işaret etmektedir. İkincisi, hegemonyanın egemen ve bağımlı sınıflar arasındaki bir rıza ilişkisi olduğundan hareket etmekte ve egemen sınıfın bu rızayı siyasi, ahlaki ve entelektüel liderlik yoluyla elde ettiğine gönderme yapmaktadır. Ancak bu rıza ilişkisi durağan değildir ve değişen tarihsel koşulların doğasına uygun olarak değişen taleplere ve tepkilere yanıt verecek şekilde sürekli olarak üretilmesi gerekmektedir (Carnoy, 2001, s. 257). Medya üzerinden üretilen ve yeniden üretilen terörizm eksenli korku söylemi ve bunun imkânlı kıldığı korku politikasının, Türkiye'de 15 Temmuz 2016 başarısı darbe girişimini izleyen süreçte muktedirlerin hegemonyasının sürdürülmesinde yeni bir araç olarak devreye girdiği ileri sürülebilir. ${ }^{1}$ Böylelikle egemen sınıfın müttefik fraksiyonları üzerindeki denetim güçlenmekte ve yaratılan korku ikliminde kitleler güçlü görünen/güçlü gördüğü iktidara adeta sığınma eğilimi sergilemektedir. Korku ikliminin kitlelerde bu sığınma eğilimini güçlendirmesine dair en çarpıcı örnek 7 Haziran ve 1 Kasım 2015 seçimleridir. İtidar partisi 7 Haziran seçimlerinde meclis çoğunluğunu kaybederken, Temmuz ayından itibaren tırmandırılan benzeri görülmemiş şiddet ve bu şiddetin yarattığı korku ikliminin de etkisiyle $1 \mathrm{Kasım}$ seçimlerinde tekrar meclis çoğunluğunu elde etmiştir. Cuma Çiçek seçim sonuçlarına ilişkin Birikim Dergisi web sitesinde yayınlanan yazısında "7 Haziran'dan beri ne değişti?" sorusuna verdiği yanıtta Doğu ve Güneydoğu illerinde Temmuz sonlarından itibaren başlayan şiddetli çatışma halini bir faktör olarak göstermektedir (Çiçek, 2015). Keza Abdullah Özkan da korku ikliminin seçmen davranışına olan etkisine şu tespitiyle katılmaktadır: "AK Parti'nin $1 \mathrm{Kasım}$ seçiminde siyasal istikrara ve ülkenin güven ve huzur içerisinde olmasının önemine dikkat çekmesi, güvenlik kaygısı taşıyan seçmenlerin ikna edilmesinde önemli bir rol üstlenmiştir" (2016, s. 28). Çok sayıda ülkede yapılan araştırmaların ölümle ilişkili konu ve olayların muhafazakâr tutumları teşvik ettiğini gösterdiğini söyleyen Castells, bu tür durumlarda insanların görüş ayrılıklarına karşı daha az hoşgörülü, kanun ve düzeni

1 İnci Özkan Kerestecioğlu, açık ya da örtülü biçimde korkunun, Türkiye'deki siyasal yaşamın ve sağ partilerin belirleyeni olduğu, iktidarların kitleleri harekete geçirme, motive ve manipüle etmede korkuyu bir araç olarak kullanmasının İkinci Meşrutiyet'e kadar uzandığı görüşündedir Bkz. Türk Sağı: Mitler, Fetişler, Düşman Imgeleri. (2016). Derleyen: Kerestecioğlu ve Özkan. İstanbul: İletişim Yayınları, s. 42. 
tesis etmeye dönük politikalara daha eğilimli ve daha milliyetçi olduğunu ileri sürmektedir (2009, s. 169).

O halde en basit haliyle insanın tehlike ve tehditler karşısında gösterdiği duygusal tepki olarak tarif edilebilecek olan korkunun, bireysel ve toplumsal tutum ve davranışların şekillenmesinde rol oynadığı söylenebilir. Korku, tehlike ve tehdit algısıyla doğrudan ilintilidir. Tehlike ve tehditlerin gerçek ve potansiyel olmasına bağlı olarak da şiddeti artmakta ya da azalmaktadır. Furedi'nin de işaret ettiği gibi "Korku zihinlere hâkim hale gelince, dünyadaki sorunlar ve zorluklar abartılmaya ve olası çözüm yolları göz ardı edilmeye başlanır. Korku ve panik kendi kendini haklı çıkaran bir dinamiğe sahiptir." (2014, s. 13). Bunun sonucunda insanın özne olarak sorunların üstesinden gelme kabiliyetine olan inanç, erozyona uğramakta ve bir korku kültürü topluma hâkim olmaktadır. Bu durumun kolektif bir teslimiyet duygusu yarattığına dikkat çeken Furedi "Bu teslimiyet duygusunun yarattığı cesaretsizlik, bizim ve gelecek nesillerin risk almaktan korkması tehdidini barındırıyor. Öznenin bu şekilde yok edilmesi, hümanist projenin önünde büyük bir engel teşkil ediyor." (2014, s. 239) ifadesiyle uyarıcı bir sosyolojik tespitte bulunmaktadır.

Makale açısından da öznenin bu şekilde yok edilmesinin ya da diğer bir ifadeyle içinin boşaltılması sürecinin nasıl işlediği önem taşımaktadır. Bu noktada günümüz Türkiye'sinde bu sürecin korku politikası temelinde işlediğini söylemek yanlış olmayacaktır. Çünkü korku politikası, "siyasal ve toplumsal düzeyde paranoya üreterek, yurttaşları sonu gelmeyen bir teyakkuz haline sokar" (Parlak, 2015, s. 537). Siyasal iktidarın manipülasyonuyla müteyakkız duruma gelen yurttaş, özgür düşünen özne konumundan çıkar, yaratılan "düşman" cephenin karşısında iktidarın tüm uygulamalarına onay veren içi boşaltılmış öznelere dönüşür. Bu durumu bireylerin nesneleşmeye mahkûm oluşu olarak tarif eden Parlak, korkunun ürettiği tehdit ve kaygı halinin süreklilik kazanmasının da uzun vadede toplumsal itaati güçlendireceğine dikkat çekmektedir (2015, s. 538). Buradan hareketle toplumsal itaatin güçlenmesinin muktedirler açısından hegemonyanın yeniden üretiminin kolaylaşması, karşı hegemonya kurma mücadelesinin ise zorlaşması anlamına geleceği söylenebilir.

Parlak'ın yurttaşların düşünen özne halinden çıkarılıp itaat eden yığınlar haline dönüştürülmesini yani özne olmaktan çıkıp nesneleşmesi tespitini, günümüz kapitalizminin depolitize olmuş koşullarını neo-liberal ve militarist postpolitika olarak kavramsallaştıran Taşkale'nin yaklaşımları da desteklemektedir. Neo-liberalizm insanları ekonomik özgürlük elde etmek ve varlığını biyolojik olarak sürdürmekten başka bir hedefi olmayan edilgen izleyicilere dönüştürmektedir. Neo-liberal denetim özneye gerçekten var olabileceği hiçbir özgürlük alanı bırakmamaktadır (Taşkale, 2015, s. 180). "Güvenlik" sözcüğünün neo-liberal kapitalizmde en yüce kavramlardan biri haline geldiğine işaret eden Taşkale, güvenlik gösterisinin sürekli kılınması gerektiğini ve bunun için kötü terörist figürünün fetişleştirilmesinin şart olduğundan söz etmektedir (2015, s. 210). 
Korku politikasına imkân sağlayan korku söylemi ve korku kültürünün medya üzerinden üretilmesinin muktedirler açısından ne kadar önemli olduğu tam da bu noktada ortaya çıkmaktadır.

Muktedirlerin korku teması üretmelerinin veya var olan korkuları manipüle etmelerinin ya da en azından sürekli gündemde tutmaya çalışmalarının iktidarlarının meşruiyetini sağlamayla doğrudan ilintili olduğunu ileri süren Kerestecioğlu, korku söyleminin siyasal alandaki işlevini şöyle açıklamaktadır (2016, s. 37):

Korku, beraberinde koruyucu-kurtarıcı motifini de getirir. Topluma "ciddi bir tehlike içindeyiz ama biz bu tehlikeden sizi koruyacağız" mesajı verilir. Bu tehlikeyi yaratan, korkunun kaynağı olan "günah keçisi" motifi de söylemin ayrılmaz bir parçasıdır. Kurtarıcının topluma yönelik söylevinde, "tehlike var, sorumlusu siz değilsiniz; bu tehlike hepimize yönelmiş durumda. Ama merak etmeyin, biz sizi bundan kurtaracağız" denmektedir. Yani madalyonun bir yüzü korkuysa, diğer yüzü kurtarıcıdır. Kurtarıcı figürü ya da kurtarma programı, yatay ilişkileri engelleyici, siyasal alanı daraltıcı bir programdır: Korku, günah keçisi ve kurtarıcı üçgeninde seyreden siyasal alan, toplumdan itaat bekler. Bunu yapmayanlar, genellikle esnek ve muğlak bir biçimde tanımlanan "günah keçisi" figürünün bir parçası haline kolayca getirilirler. Bu söylem ne kadar etkili ve güçlüyse, rejim de kendi içine o denli kapanır.

İktidar, 15 Temmuz 2016 tarihinden itibaren günah keçisi figürü olarak kurguladığı FETÖ-PKK-PYD üzerinden kendisine itaat etmeyen toplumsal kesimleri bu figürün bir parçası olarak damgalamaktadır. Makale özelinde bu unsur Cumhuriyet gazetesidir. Gazeteye yapılan operasyon, iktidar tarafından Kerestecioğlu'nun sözünü ettiği "kurtarıcı" görevinin yerine getirilmesi anlamına gelmektedir.

"Günah keçisi" kavramı karanlık ortaçağ dönemindeki "cadı avı"ndan geçen yüzyıldaki Yahudi Soykırımı'na dek tarih boyunca değişik biçimlerde ortaya çıkan vahşi uygulamalara gönderme yapmaktadır. Araştırmacılar dinsel metinlere kadar bu kavramın izlerini sürmüşlerdir (Girard, R., 1986; Campbell. C., 2013). Kavramın temelinde suçluluk duygumuzu başka yere yönlendirmek ve sorumluluk almaktan kurtulmak için başkalarını suçlama edimi yatmaktadır. Başımıza gelen kötülüklerin, felaketlerin sebebi bizim kendi eksikliklerimiz değil, suçladığımız kişilerdir. Onlar, yaratılan günah keçileridir. Tüm sorumluluğu onların üstüne yıkarak kendi sorumluluğumuzu örter ve suçluluk duygusundan kurtuluruz. Yöneticiler günah keçisini yaratır, ama onun kaderini paylaşmaz. Bu nedenle birbirine sıkı sıkıya bağlıdırlar; adeta bir madalyonun iki yüzü gibidirler. Düşmanları hakkında bir korku yaratırlar ve bunu kendi güçlerini artırmak için yaparlar. Eğer onlar çok zorlu iseler o zaman olağanüstü özel önlemlere başvurma hakları doğar. Böylelikle hukuk ve adaleti devre dışı bırakmaları mümkün olur (Campbell, 2013).

Muktedirlerin günah keçisi yaratma ve böylelikle kitleleri siyasal çıkarları doğrultusunda manipüle etmede sıklıkla komplo söylemine başvurdukları da 
bilinen bir gerçektir. İşlerin kötü gitmesinde bir "yabancı parmağı" vardır ve bu odak, içerdeki bir "azınlık" kesimi kendi çıkarına uygun şekilde kullanarak çoğunluğa "ihanet" eder konuma getirmektedir. Iktidarlar, ihanete uğradığına ikna edilen kitlelerin öfke ve nefretini bu kesim üzerine yönelterek, kendi eksikliklerini ve hatalarını gizlemeyi başarmaktadırlar. Serge Moscovici, komplo zihniyetinin devrede olması için bir azınığın komplo faaliyeti içinde olmasının da gerekmediğini, bizzat azınlığının varlığının bir komplodan söz etmek için yeterli olduğunu ve komplo zihniyetinin buna dayandığını söylemektedir. Kitleler azınlığı güvenliği tehdit eden düşman olarak görmekte ve bu düşmana karşı savaşacak askerler olarak safa geçmektedirler. Böylelikle komplo zihniyeti iktidarın kitleleri seferber etmede stratejik bir araca dönüşmektedir (Moscovici, 1987, s. 151-169).

Düşman yaratma ve komplocu söylemin 30 Mart 2014 yerel seçimlerinde AKP'nin seçim stratejilerine nasıl yansıdığı ve bu söylemin siyasal işlevini inceleyen Parlak ve Uz, iktidar partisinin kendisini "mazlum özne", Gülen Cemaati'ni "zalim özne" olarak kurgulayarak 17/25 Aralık soruşturmalarıyla yaşadığı siyasal krize rağmen "tek iyi ve haklı aktör" olarak görünebildiğine işaret etmişlerdir (2015, s. 69-106).

Daha önce dikkat çekildiği gibi medyanın siyasal iktidarla iç içe geçen yapısı, yani onun devletin ideolojik aygıtı olarak gördüğü işlev, hem genel olarak dünya çapında hem de özel olarak Türkiye somutunda siyasal iktidarların çıkarlarını ilerletmede muktedirler açısından paha biçilmez değerdedir. 11 Eylül 2001 'de ABD'de gerçekleştirilen terör saldırılarının ardından Bush yönetiminin El Kaide'yi bahane ederek terörizme karşı savaş söylemiyle Afganistan ve ardından Irak'a harekât düzenleyebilmesi, medyanın terörizm ve kitle imha silahları eksenli dezenformasyon kampanyalarıyla inşa ettiği korku söylemi ve bunun sonucunda sağlanan kamuoyu desteği ile mümkün olmuştur. Benzer şekilde Türkiye'de 15 Temmuz 2016'daki başarısız darbe girişiminin ardından medya marifetiyle oluşturulan korku söylemi, bir siyasal araca dönüşmüş ve siyasal iktidara muhalif olan kesim ve yayın organlarına dönük yaygın bir soruşturma dalgasını imkânlı kılmıştır. Bu korku söyleminin eksenini, medyada muhalif kesimlerin FETÖ, Türkiye'de faaliyet gösteren Kürdistan İşçi Partisi (PKK) ve Suriye'de faaliyet gösteren Demokratik Birlik Partisi (PYD) ile özdeşleştirilmesi oluşturmaktadır. Birbirinden farklı yapıların bir arada kullanılmasının yarattığı güçlü etkinin kamuoyu nezdinde iktidarın muhaliflerinin tasfiyesine yönelik girişimlerini kolaylaştıracağı açıktır. 31 Ekim 2016'da Cumhuriyet gazetesine dönük olarak başlatılan soruşturma bu açıdan dikkat çekicidir. Cumhuriyet ile yaşıt olan, üniter devlet anlayışına sıkı sıkıya bağlı ve askeri darbelere kategorik olarak karşı duruşuyla bilinen bir yayın kuruluşunun FETÖ ve PKK ile özdeşleştirilerek soruşturmaya tabi tutulması ve bir kısım çalışanın tutuklanması, korku söyleminin siyasal bir araca dönüştürülmesinin somut bir örneğini oluşturmaktadır. Makalenin araştırma konusu olması da bu yüzdendir. 
Anti-demokratik rejimler, illiberal demokrasiler ve faşist/askeri diktatörlüklerde muhalefeti sindirmek için korku politikasının izlenmesi siyasal tarih açısından yeni bir olgu değildir. Bu makalede her ne kadar Furedi ve Altheide'den yola çıkılarak korku söylemi ve korku kültürü Türkiye somutunda sorunsallaştırılmış olsa da yazarlardan farklı olarak asıl dikkat çekilmek istenilen nokta, korku söyleminin siyasal bir araç olarak kullanılmasıdır. Diğer bir ifadeyle vurgulanmak istenilen korku söyleminin, medya marifetiyle çoğunluğun bir avuç azınlığın çıkarına olacak şekilde manipüle edilmesinin bir aracı haline dönüştürülmesidir.

\section{Araştırma Yöntemi}

Türkiye'de medyada korku söyleminin Cumhuriyet gazetesine 31 Ekim 2016 tarihinde yapılan operasyon somutunda nası inşa edildiğinin araştırılmasında nitel araştırma yöntemi kullanılacaktır. Nicel araştırmanın aksine nitel araştırmada yöntemle ilgili somut bir şekilde belirlenmiş süreçler çoğu kez söz konusu değildir. Nitel araştırmalarda kanıt için tek bir örnekleme ve tek bir kaynağa dayanılmaz; var olan ve erişilebilen her kaynak kullanılır. Veri kaynakları insanlar ve maddeler olabileceği gibi, resmi kayıtlar, mektuplar, gazete haberleri, günlükler, raporlar, ilgili konuda basılmış yazılar ve görüntülü kayıtlar da olabilir (Eisner'den aktaran: Erdoğan, 2012, s. 113-114.).

Araştırma çerçevesinde korku söyleminin inşasına ilişkin veriler 1 Kasım 2016 tarihinde iktidar yanlısı olarak bilinen Sabah, Takvim, Yeni Şafak, Star, Türkiye, Yeni Akit, Akşam, Güneş, Milliyet, Vatan, Habertürk, Yeni Asya, Yeni Birlik ile iktidarın baskı politikaları yüzünden muhalefet özelliğinden söz edilemeyecek ancak diğer gazeteler kadar da iktidarla özdeşleşmemiş olan Hürriyet gazetesinin birinci sayfalarında aranacaktır. ${ }^{2}$ Hürriyetgazetesinin araştırmaya dâhil edilmesinin nedeni iktidar baskısının sonucunda Türk basınının "amiral gemisi" olarak nitelendirilen ve ana akım medyayı temsil eden bir basın organının dahi korku kültürünün oluşturulmasında bir işlev görüyor olmasını örneklemesidir. Evrensel, BirGün, Yurt ve Sözcü gibi muhalif gazetelerin araştırmaya dâhil edilmemesinin nedeni ise bu gazetelerin makale konusu çerçevesinde korku kültürü oluşmasına hizmet edecek korku söyleminin üretilmesinde ve yeniden üretilmesinde bir rol oynamamalarıdır. Tam tersine bu gazeteler 1 Kasım 2016 tarihli sayılarında Cumhuriyet gazetesine yapılan operasyonu sert tepki göstermişler, bunun muhalefeti sindirme ve susturma operasyonu olduğu ekseninde söylem inşasına gitmişlerdir.

Araştırmanın gazetelerin birinci sayfaları üzerinden yapılmasının nedeni bu sayfanın yazı işlerinde kamuoyuna hangi mesajın nasıl verileceğine dair kararın alındığı kritik sayfa olmasındandır. Tuchman, genel olarak gazeteye girecek

2 Diriliş Postası ve spor gazeteleri dışında 1 Kasım tarihinde yayımlanan tüm gazeteler Cumhuriyet gazetesine operasyon haberine yer vermiştir. 
haberlerin özel olarak da birinci sayfadan görülecek olanların yazı işlerinde "haber değeri müzakeresi"nin bir sonucu olduğuna işaret etmektedir (1980, s. 31-34). Gündelik rutinde birinci sayfaya özel yapılan bir toplantıyla bir haberin gazetenin yayın politikasına uygun olarak hangi yönünün belirgin ve dikkat çekici hale getirileceği saptanmaktadır. Birinci sayfanın en titiz şekilde haber "çerçevelemesi" yapılan sayfa olduğunu söylemek abartılı olmayacaktır (Aşkın, 2015, s. 111-112). Entman'a göre haberlerin çerçevelenmesi okuyucularda istenilen reaksiyonların gösterilmesini sağlamak amacıyla gerçeğin kimi yönlerinin belirgin hale getirilmesi, kimi yönlerinin de karartılması işlemidir (1993, s. 55). Van Dijk, haberin okuyucu tarafından fark edilecek, anlaşılacak, akılda tutulacak ve doğruluğuna inanılacak biçimde içeriğinin düzenlendiğine işaret etmektedir. Bu amaçla haber içeriğinde olayların olgusal niteliğinin vurgulanması, olgular arasında güçlü ilişkiler kurulması ve duygusal ve tutumsal bilgilere yer verilmesinden söz etmektedir (1988, s. 8486). Dolayısıyla genel olarak bir haberin yazımında özel olarak da birinci sayfada o haberin sunumunda neyin ön plana alındığı, neyin görmezden gelindiği yayın politikasının ve onun temellendiği toplumsal, kültürel ve siyasal şekillenmenin bir yansıması olduğu söylenebilir. Söz konusu gazetelerin birinci sayfalarında Cumhuriyet gazetesine yönelik operasyona ilişkin haberlerin incelenmesinde bu durum göz önünde tutulacak ve metinlerde söylemin nasıl kurulduğu ESA söylem stratejilerine başvurularak ortaya konulacaktır.

ESA, esas olarak açık ya da örtülü biçimde dilde kendini açığa vuran yapısal tahakküm, ayrımcılık, iktidar ve denetim ilişkilerinin analiz edilmesiyle ilgilidir. Diğer bir ifadeyle ESA, dil kullanımıyla ya da söylemde ifade edilen, işaret edilen, oluşturulan ve meşrulaştırılan toplumsal eşitsizliği eleştirel olarak araştırmayı hedefler (Wodak, 2001a, s. 2-3).

ESA alanında çalışmalarıyla tanınan Teun van Dijk, Principles of Critical Discourse Analysis makalesinde, toplumdaki her türlü tahakküm ilişkisinin yeniden üretilmesinde söylemin işlevine dikkat çekmekte ve ESA'nın her şeyden önce iktidarın kötüye kullanımının söylemsel boyutlarıyla ve bu kötüye kullanımın sonucu olan eşitsizlik ve adaletsizlikle ilgilenmesi gerektiğinden söz etmektedir. Ona göre böylesi bir kuramsal çabanın merkezinde iktidar/tahakküm ve söylem arasındaki çok yönlü ilişkilerin analiz edilmesi yer almaktadır (1993, s. 252).

Fairclough, ESA'nın sosyal bilimler alanında yapılan araştırmalarda kullanılabilecek bir yöntem olduğu kadar bir kuram ya da dil ve daha genel olarak anlam kurulmasına ilişkin kuramsal bir bakış açısı olduğunu ileri sürmektedir. Ona göre söylem toplumsal pratiklerin bir anıdır ve bu pratikler birbirleriyle diyalektik ilişki içinde olan üretim faaliyeti, üretim araçları, toplumsal ilişkiler, toplumsal kimlikler, kültürel değerler, bilinç ve anlam kurmayı içerir. ESA, toplumsal pratiklerin diğer unsurlarıyla anlam kurma arasındaki diyalektik ilişkiyi analiz eder (Fairclough, 2001, s. 121-123). 
O halde iktidar/tahakküm, dil ve dil aracılığıyla kurulan söylem arasında karşı।ıklı bir etkileşim, hatta bir iç içe geçişten söz edilebilir. İktidar ve tahakküm ilişkileri bir toplumda hâkim söylemlerin içine gömülüdür, orada yeniden üretilirler. Bu şekilde doğal ve meşru görünürler ve benimsenirler. Fairclough bu durumu "söylemin içinde icra edilen gizli iktidar" olarak tarif eder (1989, s. 49). Söylemin haber biçimiyle üretildiği ve yeniden üretildiği platformlardan biri ve en önemlisi medyadır. Althusser'in izinden gidildiğinde de devletin ideolojik aygıtı olan medyada üretilen söylem, kaçınılmaz olarak iktidar ve tahakküm ilişkisinin meşrulaştırıması ve doğallaştııımasına dönüktür. ESA, yukardan aşağıya muktedirler tarafından medya üzerinden kurulan sözü edilen hâkim söylemlerin eşitsiz ve tahakkümcü yapısını açığa çıkarmayı amaç edinir. Böylelikle aşağıdan yukarıya doğru karşı söylemin inşası için de zemin yaratır.

Bugün gelinen noktada ESA'nın altı temel söylem analizi yaklaşımını içerdiği söylenmektedir (Arcan, 2010, s. 121-122):

1. Fairclough tarafından kavramsallaştırılan ve Marksist gelenekten beslenen, Halliday'in işlevsel dil kuramını ve Foucault'nun çalışmalarını dikkate alan Diyalektik-Ilişkisel Yaklaşım, toplumsal çatışmalara yoğunlaşır.

2. Van Dijk tarafından kavramsallaştııılan, Moscovici'nin "Toplumsal Yeniden Temsiliyet" kuramını dikkate alan Sosyobilişsel Yaklaşım, başta ırkçılık olmak üzere toplumsal eşitsizliklere odaklanır.

3. Wodak ve Reisigl tarafından kavramsallaştıılan, "eleştirel kuram" ve "sembolik etkileşimcilik"ten beslenen Söylem-Tarihsel Yaklaşım, tarihsel bağlamda politik alana odaklanır.

4. Van Leeuven tarafından kavramsallaştırılan yine "eleştirel kuram" kaynaklı Toplumsal Aktörler Yaklaşımı, bireysel aktörlerin sosyal yapıyı yeniden üretimi üzerine yoğunlaşır.

5. Gerlinde Mautner tarafından kavramsallaştırılan Dilbilimsel Külliyat Yaklaşımı, sayısal analiz araçları sağlamaya yönelir.

6. Siegfried Jager ve Florentine Maier tarafından kavramsallaştırılan, Foucault'nun yapısalcı söylem fikrinden etkilenen Dispositif Analiz Yaklaşımı, özne ve nesne arasındaki söylemsel dolayıma yoğunlaşır.

Bu makalede söylem stratejilerinden yararlanılacak olan ESA yaklaşımlarından söylem-tarihsel yaklaşım (STY), dil ile iktidar arasındaki ilişkiyle ilgilenir ve tarihsel bağlam içinde politik alana yönelir. STY'nin ayırt edici özelliği, bir söylemde saf dil bilimsel boyutu aşarak, tarihsel, siyasal, toplumsal ve psikolojik boyutları analize dâhil etmeye çalışmasıdır (Tekin, 2008, s. 733). Araştırma yöntemi olarak diğer ESA yaklaşımları arasından seçilmesinin nedeni de budur. Çünkü Cumhuriyet gazetesi operasyonu korku söyleminin üretildiği politik bağlamın bir tezahürü olarak makalenin sorunsalını oluşturmaktadır. Araşıırma asıl olarak siyasal söylem stratejilerinin nasıl oluşturulduğuyla ilgili olduğu için daha çok metnin makro ve mikro yapıları ve zihinsel modellerle ilgilenen van Dijk'ın sosyobilişsel yaklaşımı tercih edilmemiştir. 
Wodak, STY'nin en önemli özelliklerini şu şekilde sıralamaktadır (2001b, s. 69-70):

- Yaklaşım disiplinlerarasıdır.

- Disiplinlerarasılık kuram, araştırma, ekipler ve pratik olmak üzere farklı düzeylerde söz konusudur.

- Yaklaşım sorun yönelimlidir, belirli dilbilimsel konulara odaklanmaz.

- Yöntem kadar kuram da eklektiktir: Araştırma konusunun açıklanmasına ve anlaşılmasına yardımcı olan kuramlar ve yöntemler kullanılır.

- Inceleme, daha ileri analizleri ve kuramsallaştırmaların bir önkoşulu olarak üzerine odaklanılan konuyu araştırmak için her zaman saha çalışmasını ve etnografiyi işin içine dâhil eder.

- Yaklaşım sabit değildir, kuram ve ampirik veriler arasında sürekli olarak geliş ve gidişleri gerektirir.

- Çoklu türler ve çoklu kamusal uzamlar incelenir ve metinler arası ve söylemler arası ilişkiler araştırıır. Yeniden bağlamsallaştırma, konu ve uslamlamaların olduğu kadar bu türlerin de arasında ilişki kurulmasında en önemli ișlemdir.

- Tarihsel bağlam her zaman analiz edilir ve söylemlerin ve metinlerin yorumlanmasına dâhil edilir.

- Büyük kuramlar bir temel olarak işlev görür. Özgül analizlerde orta düzeyli kuramlar analitik amaçlara daha iyi hizmet eder. ${ }^{3}$

- Pratik hedeftir. Sonuçların farklı alanlardaki uzmanların erişimine açıması ve ikinci bir adım olarak belirli söylemsel ve toplumsal pratiklerin değiştirilmesi amacıyla kullanılması gerekir.

Bu ilkeler çerçevesinde STY, genel olarak üç aşamada uygulanır. Illk olarak bir söylemdeki özgün içerikler ya da konular tespit edilir. İkinci olarak söylemsel stratejiler araştırılır ve son olarak bu söylemsel stratejilerde kullanılan, örneğin metafor gibi dilsel araçlara bakılır. STY söylemin nasıl inşa edildiğini çözümlemede esas olarak adlandırma, hüküm, uslamlama, bakış açısı edindirme ve önemsemehafifseme olmak üzere beş söylemsel stratejiyi öne çıkarmaktadır. Burada adlandırma söylemdeki kişi, grup ya da toplumsal kesimlerin dilsel olarak nasıl gösterildikleriyle, onlardan nasıl söz edildikleriyle, aidiyet kategorilerinin nasıl inşa edildiğiyle, yani grup içi mi yoksa grup dışı kimlikler mi atfedildiğiyle ilgilidir. Hüküm stratejisi bir söylemdeki kişi, grup, toplumsal kesim veya aktörlerin damgalanması, olumlu ya da olumsuz, övücü ya da yerici biçimde gösterilmesine dönük ifadelerin kullanılmasına işaret eder. Uslamlama olumlu ya da olumsuz niteliklerin, "biz" ve "öteki" ayrımlarının haklı gösterilmesine ve meşrulaştııımasına dönük ifadelerin kullanıması; kişi, grup ya da toplumsal kesimlere dönük eylemlerin haklı gösterilecek şekilde söylemde gerekçelendirilmesi stratejisidir. Bakış açısı edindirme stratejisi okuyucu, izleyici ya da dinleyicinin söylemi kuran kişi ya da odağın bakış açısından söylem konusuna bakmasının sağlanmasına yöneliktir. Bu stratejiye çerçeveleme ya da söylem temsil stratejisi de denir. Söylemdeki adlandırmaların, hükümlerin ve uslamlamaların hangi açıdan anlaşılması gerektiğine işaret eder. Önemseme-hafifseme stratejisi ise bir olgunun

3 Büyük (genel) kuram, orta düzeyli kuram ve ampirik genellemeler hiyerarşisine ilişkin bkz. Morgan. E. C. (2004). Collective Political Violence. Great Britain: Routledge, s. 7-8. 
olduğundan daha önemli ya da daha önemsiz gösterilmesine dönük ifadelerin kullanılmasıdır. Böylelikle söylem yoluyla ayrımcılığa, ötekileştirmeye ve şeytan gibi göstermeye katkı sağlanır (Wodak, 2001b, s. 72- 73; Reisigl ve Wodak, 2001, s. 44-45). O halde bütün bunlara paralel olarak bir metinde STY temelli eleştirel söylem analizi yoluyla iktidar, eşitsizlik ya da tahakküm ilişkisi açığa çıkarılacaksa şu sorulara yanıt aranması doğru olacaktır:

1. Söylemin adlandırma stratejisi nasıl inşa edilmiştir?

2. Söylemin hüküm stratejisi nasıl inşa edilmiştir?

3. Söylemin uslamlama stratejisi nasıl inşa edilmiştir?

4. Söylemin bakış açısı edindirme, çerçeveleme, stratejileri nasıl inşa edilmiştir?

5. Söylemin önemseme, hafifseme stratejisi nasıl inşa edilmiştir?

Gazetelerin birinci sayfaları üzerinde yapılacak araştırmada bu beş soruya yanıt verilmeye çalışılarak Türkiye' de 15 Temmuz 2016 başarısız darbe girişiminin ardından korku söyleminin medya üzerinden nasıl kurulduğu ortaya konulacaktır. Bu noktada yukarıda sayılan beş söylem stratejisinin tamamının bir metinde söylem analizinde kullanılması şartının olmadığını, kimi durumlarda bir kısmının metne uygun olabileceğini söylemek yerinde olacaktır. Yani yöntem olarak STY'den yararlanan bir araştırmacı seçilen konu ve metnin somut durumuna göre hangi söylem stratejilerinin analizini yapacağına karar verir (Düzgit, 2014). Diğer taraftan yukarıda işaret edilen STY'nin üç aşamalı söylem analizi şemasındaki ikinci ve üçüncü aşamalara ilişkin işlemlerin birlikte yapıldığının belirtilmesi yerinde olacaktır. Yani Cumhuriyet gazetesinin FETÖ, PKK ve PYD gibi örgütlerle özdeşleştirilmesinin konu olarak belirlenmesinden sonra ikinci aşamada söylem stratejilerinin nasıl kurulduğu ve bu stratejilerin kurulmasında kullanılan dilsel araçlar birlikte araştırımıştır.

Çalışmanın 1 Kasım 2016 tarihinde yayımlanan 14 gazete üzerinden yapılması araştırmanın sınırıı̆ı̆ını oluşturmaktadır. Daha fazla sayıda gazete üzerinden ve daha geniş zaman aralığında yapılacak bir araştırma, korku söylemi ve korku politikasının nasıl devam ettirildiğinin gösterilmesi açısından, diğer bir ifadeyle sistematikliğinin vurgulanması ve bu çalışmanın tamamlayıcısı olması açısından önem taşıyacaktır.

\section{Analiz ve Bulgular}

Cumhuriyet gazetesine 31 Ekim 2016 günü düzenlenen operasyon, 15 Temmuz başarısız darbe girişimin ardından OHAL ilan eden iktidar partisinin kendisine muhalif olan tüm kesimleri, susturmak ve sindirmek için birbirinden farklı üç örgütle (FETÖ, PKK ve PYD ) özdeşleştirerek "şeytanileştirdiği" ve antidemokratik uygulamalara kamuoyu desteğini sağlamaya çalıştığı bir ortamda gerçekleştirilmiştir. 
Bu tarihsel ve siyasal bağlamda Cumhuriyet gazetesine yönelik operasyonla ilgili seçilen 14 gazetenin 1 Kasım 2016 tarihli birinci sayfalarında yer alan haberler ve bu haberlerdeki söylem inşası şöyledir:

Sabah gazetesinde "CUMHURIYET'TEKI FETÖ-PKK'LI YAPILANMAYA SORUŞTURMA" başlı̆ıyla verilen haberde "Cumhuriyet gazetesini FETÖ ve PKK destekçisi bir yayın organına dönüştürmekle eleştirilen yönetici ve yazar ekibine operasyon düzenlendi.", "FETÖ'cü Zaman gazetesiyle aynı manşetleri atan ekibe yönelik suçlamalar şöyle: FETÖ, PKK ve PYD örgütlerine yardımcı olmak, meşru göstermek, eylemlerini övmek, 15 Temmuz darbe girişimini meşrulaştıııı yayın yapmak." ifadeleri yer alıyordu.

Mizanpaj açısından bakıldığında haberin birinci sayfada FETÖ'yü teşhir eden bir manşet haberinin içine, gazetecilik jargonuyla ifade etmek gerekirse, "gömüldüğü" ya da manşetle birlikte "paketlendiği", Zaman gazetesi ile Cumhuriyet' in aynı ifadeleri taşıyan geçmiş iki sayısına ait birinci sayfa kupürlerinin "Cumhuriyet nasıl FETÖ çizgisine geldi?" ifadesiyle verildiği ve "Cumhuriyet'in terör arşivi" ifadesiyle iç sayfalara gönderme yapıldığı dikkat çekmektedir.

STY açısından Sabah gazetesinde Cumhuriyet gazetesiyle ilgili haberdeki uslamlama stratejisi, gazetenin FETÖ, PKK ve PYD'ye yardım ettiği için operasyona maruz kaldığı ekseninde kurulmaktadır. Haber başlığı bile kendi başına Cumhuriyet gazetesiyle ilgili "suç ispatlana kadar sanık masumdur" hukuk karinesinin açıkça görmezden gelinmesidir. Adlandırma stratejisi, daha önce yapılan haberlerdeki iki başlığının çakışması nedeniyle Cumhuriyet gazetesi ile "FETÖ'cü Zaman gazetesi" nin özdeşleştirilmesine dayanmaktadır. Íki gazetenin kupürlerinin altında "Cumhuriyet Nasıl FETÖ Çizgisine Geldi?" ifadesi, Cumhuriyet eşittir Zaman eşittir FETÖ anlamına gelmektedir. Haberdeki hüküm stratejisi, Cumhuriyet gazetesinin FETÖ, PKK ve PYD örgütlerine yardım ettiği, onları meşru gösterdiği ve eylemlerini övdüğü ifade edilerek oluşturulmaktadır. Söylemin bakış açısı edindirme stratejisi Cumhuriyet'e operasyon haberinin " 54 milyonluk vurgun" manşet haberiyle birlikte verilerek kurulmaktadır. Bu şekilde, Cumhuriyet gazetesine operasyonun 15 Temmuz'dan beri Türkiye'nin en büyük sorunu olarak gündemleştirilen FETÖ ile mücadele çerçevesinde yapıldığı algısının yaratılması hedeflenmektedir. Keza söylemin önemseme/hafifseme stratejisinin de aynı şekilde kurulduğu söylenebilir. Sabah'taki söyleme göre Cumhuriyet gazetesine operasyon yapılması önemlidir, çünkü gazete FETÖ ile aynı çizgide faaliyet göstermektedir ve söz konusu örgüt de bugün ülkenin en büyük sorunudur. Önemli olan devletin bekasıdır. Öte yandan Cumhuriyet gazetesinin habercilik faaliyeti, operasyon yapılmayı hak eden bir gazete olması nedeniyle hafifsenmektedir. "Cumhuriyet'in terör arşivi" ifadesi söylem kurulumunda bir dilsel araç olarak değerlendirilebilir. Gazetelerin arşiv bölümlerine gönderme yapan bu ifade Cumhuriyet in "terör destekçisi" olarak damgalanmasına hizmet etmektedir. 
Sabah gibi Turkuvaz Grubu'nun yayını olan Takvim gazetesi, Cumhuriyet gazetesine operasyon haberini ABD'de FBI'ın ülkeye gelen FETÖ'cülerin ilk uğradıkları yer olduğu ileri sürülen Masal Cafe'ye yaptığı baskınla ilgili manşet haberinin sol kısmından vermiştir. Can Dündar'ı ima eden "Cumhuriyet'e CANLI OPERASYON" başlığıyla verilen haberde söylemin uslamlama stratejisi, haberin birinci spotundaki "FETÖ ve PKK propagandası yapan gazete basıldı" ifadesiyle kurulmuştur. Yani bu iki örgütün propagandasını yaptığı için Cumhuriyet gazetesi operasyona hedef olmuştur. "Suç dosyası" ifadesi altında gazetenin değişik tarihlerde yayınladığı dört habere işaret eden ifadeler, söylemin hüküm stratejisi olarak değerlendirilebilir. Bu bölümde Cumhuriyet gazetesinin, Sabah gazetesinde yapıldığı gibi FETÖ'nün yayın organı olarak gösterilen Zaman gazetesi ile ortak manşetler attığından, örgütün servis ettiği haberleri yayınlayarak algı operasyonu yaptığından, MiT TIR'ları görüntülerini manşete taşıyarak Türkiye'ye iftira attığından ve PKK lideri Cemil Bayık ile röportaj yaparak örgütü "yere izmarit atmayan" çevreci bir yapı olarak tanıttığından söz edilmektedir. Söylemin bakış açısı edindirme stratejisinin de mizanpaj marifetiyle kurulduğu söylenebilir. Cumhuriyet haberinin manşetteki "Masal Bitti!" haberinin altından verilmesi ve haberin içinde FETÖ ile yukarda sözü edilen ilişkilendirmelerin yapılması okuyucuya haberi hangi çerçeveden okuması gerektiği yönünde mesaj vermektedir. Gazetenin haber başlığında Can Dündar'ı ima eden ifade ise dilsel araç kullanımına bir örnek teşkil etmektedir.

Albayrak Grubu'nun patronajında olan Yeni Şafak gazetesinde "Teröre destek verdi, darbeyi kışkırttı" başlığıyla sürmanşetten verilen haberde "FETÖ ve PKK'nın sözcüsü gibi manşetler atan ve 15 Temmuz darbesini kışkırtıcı yayınlar yapan Cumhuriyet Gazetesi'ne operasyon yapıldı." ifadesi kullanılmaktadır. Haberin yanında kırmızı zemin içinde "iHANET manşetleri" başığını taşıyan bölümde yine Sabah gazetesinin yaptığı gibi Zaman gazetesiyle Cumhuriyet'in başlık çakışmasını gösteren gazete kupürleri ile Cumhuriyet gazetesinin dört farklı manşetine ait kupürler "Cumhuriyet gazetesi attığı manşetlerle ülkenin bütünlügünü hedef aldı. Türkiye'ye müdahale etmeye çalışan güçlerin tetikçisi gibi hareket etti." yorumuyla sunulmaktadır.

STY söylem stratejileri açısından Yeni Şafak'ın haberi değerlendirildiğinde uslamlama stratejisinin gazetenin teröre destek verdiği ve darbeyi kışkırtı̆ğı için operasyona maruz kaldığı temelinde kurulduğu görülmektedir. Adlandırma stratejisinin unsurları olarak "hain" (ihanet manşetleri), "kışkırtııı" ve "FETÖ ve PKK sözcüsü" ifadeleridir. Haber söyleminde hüküm stratejisi "Cumhuriyet ülkenin bütünlügünü hedef aldı.", "Dış güçlerin tetikçisi gibi hareket etti." ifadeleriyle kurulmuştur. Söylemin bakış açısı edindirme stratejisi haberin başlığıyla kurulmaktadır: Teröre destek verdi, darbeyi kışkırttı. Haberin asıl neyle ilgili olduğu ise alttaki resmin içine yazılan "Cumhuriyet Gazetesi'ne operasyon" ifadesiyle duyurulmaktadır. Böylece okuyucuya "Bu haberi teröre destek verilmesi, darbenin kışkırtılması bakış açısından okuyun." mesajı verilmektedir. Haberdeki söylemde önemseme/hafifseme stratejisinin ise Cumhuriyet'in 
haberciliğinin "IHANET manşetleri" ifadesiyle önemsizleştirilmesi ve "terörle işbirliği yapan" bir gazeteye karşı yapılan operasyonun devletin "meşru" eylemi olarak gösterilmesiyle kurulduğu söylenebilir.

Ethem Sancak'in patronu olduğu ESMEDYA bünyesinde yayımlanan Star gazetesinde "Cumhuriyet Vakfı'na terör operasyonu" başlığıyla verilen haberde şu ifade kullanılıyordu: Cumhuriyet Vakfı yöneticileri hakkında, "Darbeyi meşrulaştırıcı yayınlar" ve "FETÖ-PKK terör örgütlerine üye olmamakla birlikte örgüt adına suç işlemek" iddialarıyla operasyon başlatılı. Diğer gazetelere göre Star gazetesinin Cumhuriyet haberini birinci sayfadan küçük gördüğü dikkat çekmektedir. Haber söyleminde uslamlama stratejisi Cumhuriyet'in darbeyi meşrulaştırıcı yayın yaptığı ve terör örgütleri adına suç işlediği için operasyona maruz kaldığı temelinde kurulmaktadır. Haberin görsel unsuru olarak basılan resmin altındaki ifade, adlandırma stratejisinin unsuru olarak değerlendirilebilir. CHP ve HDP'lilerden oluştuğu söylenilen grubun Kışanak protestosu yaptığı ifade edilerek Cumhuriyet'in, tutuklanan HDP'li Diyarbakır Belediye Başkanı Gültan Kışanak üzerinden PKK ile yakınlığı ima edilmektedir. Keza, haberin altında gazete yazarlarından Hüseyin Gülerce'nin yazısına yapılan göndermede de "Zaman'ın Cumhuriyet'i; geçti o günler" ifadesiyle örtük biçimde Cumhuriyet, Gülen cemaati dolayısıyla da FETÖ ile özdeşleştirilmektedir. Söylemdeki hüküm stratejisinin, gazetenin "darbeyi meşrulaştırıyor" ve "terör örgütleri adına suç işliyor" ikili hattı üzerinden kurulduğu söylenebilir. Bakış açısı edindirme stratejisi Star gazetesinin "YÜZDE 100 by FETÖ" manşetiyle Cumhuriyet'e yapılan operasyon haberinin yan yana verilmesiyle kurulmaktadır. Türkiye'nin bir FETÖ sorunuyla uğraştığı ve Cumhuriyet gazetesine dönük operasyonun da bu çerçevede algılanmasına çalışımaktadır. Hem metin içinde hem de metnin altındaki resim altında gazetenin eski genel yayın yönetmenin firari olarak nitelendirilmesiyle söylemin hafifseme stratejisi kurulmakta, adeta "genel yayın yönetmenlerinin bile firarda olan bir gazeteye yapılacak operasyon mubahtır" mesajının verilmesi sağlanmaktadır.

Yeni Akit gazetesinde "iHANET BÜLTENi'ne operasyon" başığıyla verilen haberde "Terör örgütleri FETÖ ve PKK yandaşlığıyla büyük tepki toplayan Cumhuriyet gazetesi yöneticileri ve yazarlarına operasyon yapıldı. 14 kişi gözaltına alınırken, savcılık gözaltı gerekçesi olarak, FETÖ/PDY ve PKK/KCK terör örgütleri adına suç işlemenin yanı sıra yönetim kurulu toplantısında alınan vakıf üyeliğine seçim kararının usulsüz olması nedeniyle operasyon yapıldığı açıklandı." ifadesi yer alıyordu. Uğurlu Gazetecilik bünyesinde çıkarılan gazetenin haber söyleminde uslamlama stratejisi Cumhuriyet'e terör örgütleri adına suç işlediği ve vakıf yönetiminin usulsüzlük yaptığı için operasyon yapıldığı ekseninde kurulmaktadır. Söylemin adlandırma stratejisi "ihanet Bülteni", "FETÖ ve PKK yandaşı" ifadeleriyle oluşturulurken, bakış açısı edindirme stratejisi haberin başlığıyla kurulmaktadır: 'iHANET BÜLTENi'ne operasyon. Gazete bu başlığıyla haberin Cumhuriyet gazetesinin hain olduğu akılda tutularak okunması gerektiği mesajını vermektedir. Keza yine başlıkta kullanılan ifade hafifseme stratejisi olarak da değerlendirilebilir. Çünkü Yeni Akit'e göre cumhuriyetin kuruluşuyla yaşıt olan 
Cumhuriyet gazetesi, gerçek anlamda bir gazete değil, olsa olsa bir "ihanet bülteni"dir.

Cumhuriyet'e operasyon haberini "GEREKÇE: Teröre destek" başığıyla veren Ihlas Grubu'na ait Türkiye gazetesinde ise haklarında gözaltı kararı olan 18 kişinin FETÖ ve PKK'ya üye olmamakla birlikte örgüt adına suç işlediklerine dikkat çekilmektedir.

Türkiye gazetesindeki haberin söylem inşasında uslamlama stratejisi Cumhuriyet'in "teröre destek" verdiği için operasyona maruz kaldığı temelinde oluşturulmuştur. Adlandırma stratejisi, "operasyona giden yol" başlığıyla verilen kutudaki ifadelerde kendisini göstermektedir. Buna göre Cumhuriyet "casus" ile özdeştir. Hüküm stratejine ilişkin olarak aynı yerde "Cumhuriyet PKK'ya çalışıyor" mesajı öne çıkmaktadır. Haber söyleminde bakış açısı edindirme stratejisi, haberin adeta manşet haberinin bir görsel unsuru olarak sunulmasıyla etkili hale getirilmek suretiyle kurulmaktadır. "KUMPAS USTALARI" manşeti içine "gömülen" Cumhuriyet'e operasyon haberiyle, gazete Türkiye üzerine oynanan büyük oyunun bir parçasıymış gibi sunulmakta, dolayısıyla okuyucuya örtük biçimde haberin bu çerçeveden okunması gerektiği mesajı verilmektedir. Söylemdeki önemseme/hafifseme stratejisi Cumhuriyet gazetesinin "Büyüteç" başlıklı kutu içindeki konulara ilişkin yaptığı haberciliğinin gerçek bir gazetecilik değil, "casusluk", "hainlik" ve "terör destekçiliği" olduğu üzerine kurulmaktadır. Akşam gazetesinde Cumhuriyet'e yapılan operasyon birinci sayfada "KIMIN CUMHURIYETi" başlığıyla manşetten verilmiştir. Haber söylemindeki uslamlama stratejisi manşet spotundaki "Can Dündar'la birlikte geleneksel çizgisinden savrulan Cumhuriyet, ihanet odaklarının operasyonlarına gönüllü ortaklık yaptı! Savcı dün düğmeye basıp gazetenin 16 yazarı ve yöneticisi hakkında gözaltı kararı aldırdı." ifadeleriyle kurulmaktadır. Söylemin adlandırma stratejisi Cumhuriyet gazetesinin bazı haberlere ilişkin kupürlerin "FETÖ sözcüsü", "PKK destekçisi", "DHPK-C PR'cısı" ve "Batı Şakşakçısı" olarak gruplandırılmasıyla kurulmuştur. Söylemin hüküm stratejisinin "Okuyucuları bile öfkeliydi" alt başlığı ile verilen ifadelerle kurulduğunu söylemek mümkündür. Cumhuriyet bu bölümde "MiT TIR'ları ihanetine manşetten ortak olmak", "17/25 savcılarının ağzından seçilmiş iktidarı tehdit etmek", "Kandil'e üç ay arayla iki kez adam gönderip PKK'ya güzellemeler düzmek" ve "terör örgütlerinin psikolojik savaşına destek vermek" ifadeleriyle damgalanmaktadır. Bakış açısı edindirme stratejisi manşetin başlığıyla kurulmakta, Türkiye Cumhuriyeti'nin kuruluşuyla yaşıt sayılabilecek bir gazeteye yapılan operasyonun cumhuriyet rejimine "ihanet" penceresinden okunmasına çalışılmaktadır. Söylemin hafifseme stratejisi "Okuyucuları bile öfkeliydi" alt başlığıyla kurulmakta, bir basın organının muhatabı olan kitlenin bile yayın politikasına tepkili olduğu algısı yaratılmaya çalışılmakta, dolayısıyla gazetenin gerçek bir gazete olmaktan çıktığı ima edilmektedir.

Star ve Akşam ile aynı sermaye grubuna ait olan Güneş gazetesi Cumhuriyet'e operasyona birinci sayfasının tamamını ayırmasıyla dikkat 
çekmektedir. "TERÖRÜN KALESINE OPERASYON" manşetiyle verilen haberin spotunda "FETÖ ve PKK'ya verdiği destek nedeniyle terörün kalesi haline gelen Cumhuriyet Gazetesi'nin yöneticileri hakkında soruşturma başlatıldı" ifadesi yer almıştır. Bu ifadenin söylemin uslamlama stratejisine işaret ettiği söylenebilir: Cumhuriyet böyle bir operasyonu hak etmiştir, çünkü FETÖ ve PKK gibi terör örgütlerine destek vermiştir. Söylemin adlandırma stratejisi Cumhuriyet gazetesinin değişik tarihlerde yaptığı dört haberin kupürleri sayfanın sol üst kısmından "Iş̧te o ihanet manşetleri" başlığıyla verilerek kurulmaktadır. Bu şekilde Cumhuriyet "hain" olarak gösterilmekte ve damgalanmaktadır. Söylemin bakış açısı edindirme stratejisinin manşet başlığıyla verildiğini söylemek mümkündür. Böylelikle okuyucunun haberi gazetenin "terörün kalesi" olduğunu akılda tutarak okuması sağlanmaya çalışılmıştır. Diğer yandan "kale" sözcüğünün söylem inşasında dilsel bir araç olarak Cumhuriyet'i damgalamakta kullanıldığı dikkat çekmektedir.

Milliyet gazetesinin operasyon haberine birinci sayfanın en altında ve küçük bir yer ayırması dikkat çekicidir. Haberi "Cumhuriyet operasyonu" başlığıyla iç sayfalara gönderme yapan bir "anons" tarzıyla veren gazete, bu tutumuyla olayı önemsizleştirmeye çalışmıştır. Ülkenin en köklü gazetesine yapılan böylesi bir operasyonu bu şekilde haberleştiren gazetenin söylem kurulumunun hafifseme stratejisine uygun olduğunu söylemek mümkündür.

Milliyet ile aynı sermaye grubuna ait olan Vatan gazetesinde Cumhuriyet operasyonuna ilişkin haber birinci sayfanın sol alt köşesinde üsten ve alttan FETÖ ile ilgili haber ve "anons"larla çevrilmiş şekilde "Cumhuriyet Gazetesi'ne operasyon!" başlı̆ııla verilmiştir. CHP Genel Başkanı Kılıçdaroğlu'nun beyanları "Sahip çıkalım" başığıyla yer alması haberde "denge" oluşturma çabası olarak görülebilir. Söylem stratejileri açısından gazetenin haberi değerlendirildiğinde, söylemin bakış açısı edindirme stratejisi Cumhuriyet'e operasyon haberinin FETÖ haberleri içinde verilmesiyle kurulmuştur. Böylelikle okuyucunun haberi okuması istenilen bağlama işaret edilmiştir. Söylemin hafifseme stratejisi böylesi önemli bir haberin sayfanın sol alt köşesinden verilmesiyle oluşturulmuştur.

Cumhuriyet'e operasyon haberini Habertürkgazetesi birinci sayfadan gazete logosunun altında manşete ayrılan yeri ikiye bölerek sağ tarafta kalan kısımda vermiştir. "CUMHURIYET GAZETESI'NE OPERASYON" başlığını atan gazetenin kullandığı dilin "nötr" olması, hatta haberde tepkilere yer vererek operasyondan dolayı hoşnutsuzluk ima etmesi dikkat çekmektedir. Bununla birlikte haberin altında hükümet sözcüsü Numan Kurtulmuş'un operasyonla ilgili "yazarlara operasyon yok, soruşturma tüzel kişiliğe yönelik" açıklamalarına yer verilmiştir. Bu bölüm tepkilere ayrılan bölümden çok daha fazla yer kaplamakta ve daha fazla dikkat çekmektedir. Kurtulmuş'un ifadesine dayanarak "Soruşturma tüzel kişiliğe" başığının atılmasını söylemin hafifseme stratejisi olarak değerlendirmek mümkündür. Çünkü bu şekilde gazetecilere dönük bir operasyon olmadığı, dolayısıyla basın özgürlüğünün ihlalinden söz edilemeyeceği ima edilmektedir. 
Yeni Asya gazetesi ise haberi "Cumhuriyet'e 'FETÖ-PKK' operasyonu" başlığıyla vermiştir. Haberin, gazetenin manşeti olan "OLAN TÜRKIYE'YE OLUYOR" ile mizanpaj açısından bütünleştirilerek verilmesi dikkat çekmektedir. Haber başlığındaki FETÖ ve PKK sözcüklerinin tırnak içinde kullanılması ve haberin altında Türkiye Gazeteciler Sendikası ve Türkiye Gazeteciler Cemiyeti gibi muhalif mesleki örgütlerin tepkilerine yer verilmesi, Yeni Asya Yayıncılık tarafından çıkarılan Yeni Asya'nın Cumhuriyet gazetesine yapılan operasyona taraftar olmadığını göstermektedir. Bununla birlikte örgüt isimlerinin tırnak içine alınmasıyla verilmek istenilen mesajın kodunu her okuyucunun kolayca ve doğru biçimde açamayacağı göz önüne alındığında gazetenin korku söyleminin inşasına pasif bir katkı yaptığını söylemek mümkündür.

Gazeteci Avni Özgürel'in imtiyaz sahibi olarak göründüğü Forum Basın Yayın tarafından çıkarılan Yeni Birlik gazetesi Cumhuriyet'e yapılan operasyonla ilgili haberi gazete logosunun üstünden "CUMHURIYET GAZETESI OKURLARI: Cumhuriyet OLMAKTAN ÇIKMIŞTI" başlığıyla sürmanşetten vermiştir. Haberde operasyonun hangi gerekçeyle yapıldığına dair herhangi bir ifade yer almamakla birlikte Alev Coşkun'un gazetenin yayın politikasından şikâyet eden ifadelerine yer verilmiştir. Bu çerçevede söylemin uslamlama stratejisi Cumhuriyet gazetesinin eski özelliklerini taşımadığı, yani gerçek bir gazete olmaktan çıktığı için operasyona maruz kaldığı üzerine kurulmuştur. Söylemin hafifseme stratejisinin ise haberin Cumhuriyet Vakfı çerçevesinden verilmesiyle oluşturulduğu söylenebilir. Böylelikle basın özgürlüğünün ihlalinin değil sadece "usulsüz bir genel kurul"un sonuçlarının düzeltilmesinin söz konusu olduğu mesajı verilmektedir.

Hürriyet gazetesinde ise "Cumhuriyet'te 15 GÖZALTI" başlığıyla verilen haberde "17 yönetici ve yazar için FETÖ ve PKK terör örgütleri adına suç işledikleri" iddiasıyla gözaltı kararı alındığı ifade ediliyordu.

İktidar yanlısı diğer gazetelerden farkla, Hürriyet gazetesinin haberi "nötr" bir dille verdiği dikkat çekmektedir. Hatta haberde kullanılan büyük resmin içindeki "Çok sayıda basın meslek ve sivil toplum kuruluşu temsilcisi Cumhuriyet gazetesinin Şişli'deki merkezine destek ziyaretine gitti." ve küçük resmin içindeki "Yıllar önce yazdığı yazı ve kitaplarda Fethullah Gülen yapılanmasıyla ilgili iddiaları ilk gündeme getirenlerden Hikmet Çetinkaya da gözaltında." ifadeleriyle örtük biçimde Cumhuriyet gazetesine yapılan operasyona karşı olunduğu mesajını vermektedir. Bu karşı duruş, haberin altına CHP Genel Başkanı Kemal Kılıçdaroğlu'nun Cumhuriyet'e yapılan operasyonu “Karşı darbeyle karşı karşıyayız. Cumhuriyet'e ve Cumhuriyet gazetesine sahip çıkmak gerekir." ifadesinin yanı sıra Türkiye Barolar Birliği'nin "Cumhuriyet'e operasyon basın özgürlüğüne doğrudan saldırıdır." ve TÜSIAD’ın “Basının terörle bu denli yoğun ilişkilendirilmesi kamusal bir sorundur." açıklamalarıyla güçlendirilmeye çalışılmıştır. Ancak görüldüğü gibi bu karşı duruş örtük ve dolaylıdır. Gazetenin iktidarın baskısı altında olduğunun asıl göstergesi gazetenin haber değerlendirmesidir. Cumhuriyet'e operasyon haberinin haber değeri açısından gazetenin manşeti olan "Necdet 
Özel Koalisyonu" başlıklı haberden kuşkusuz çok daha yüksektir. Ancak gazete yazı işleri serbest bir yayıncılık ortamında manşete çıkacak nitelikte olmayan bir "tepki" haberini manşet yapmış, Cumhuriyet'e operasyon haberini ise ikinci sırada değerlendirmiştir.

Hürriyet gazetesinin Cumhuriyet'e operasyon haberini "nötr" dilde vermesi gazetenin "terör" örgütleriyle özdeşleştirilmesi söyleminin kurulmasında hiçbir katkısı olmadığı anlamına da gelmez. Uslamlama stratejisi açısından yine "FETÖ ve PKK terör örgütleri adına suç işledikleri" için gazeteye operasyon düzenlenmesi söz konusudur. Bakış açısı edindirme stratejisi haberin başlığının "nötr" bir ifadeyle verilmesiyle "adli bir vaka" ekseninde kurulmuştur. Oysa "basın özgürlügü̈" perspektifiyle bir başlık kurgulansaydı haberin etkisi hem çok daha farklı olur hem de medyadaki hâkim söyleme karşı bir söylem kurulmuş olurdu.

\section{Sonuç ve Tartışma}

Cumhuriyet gazetesine 31 Ekim 2016'da yapılan operasyonla ilgili yazılı basında seçilen 14 gazetenin birinci sayfalarında yer alan haberler üzerinden STY söylem stratejilerinden yararlanılarak yapılan araştırma ve çözümleme, gazetenin kamuoyunda FETÖ, PKK ve hatta PYD gibi örgütlerle aynı çizgide olduğu, onlardan destek aldığı ve onları desteklediği algısını yaratacak şekilde söylem inşa edildiğini göstermektedir. Böylelikle kamuoyunun gazeteye yapılan operasyonu haklı bulması ve desteklemesi hedeflenmiştir. Demokratik bir toplumda, hukukun temel ilkesi suçu ispatlanana kadar sanığın masumiyetinin bir karine olmasına rağmen, özellikle iktidar yanlısı basın kuruluşlarının herhangi bir adli soruşturmanın ilk aşaması olan gözaltına alma işlemini haberleştirirken Cumhuriyet gazetesine adeta suçu kanıtlanmışçasına ve o nedenle de böyle bir muameleyi hak etmişçesine davranmış olması dikkat çekicidir. Araştırma kapsamına alınan gazetelerin 31 Ekim- 06 Kasım haftasında tirajlarının toplamı 1818 567, tüm gazetelerin tiraj toplamı ise 3291 282'dir (MedyaTava, 2016). Araştırmaya konu edilen gazetelerin tirajları genel tirajın yaklaşık yüzde 55'ini oluşturmakta ve bu gazeteler ana akım medyayı ağılıklı olarak temsil etmektedirler. Gazetelerin tiraj ve ana akım medyayı temsil kapasitelerinin Cumhuriyet gazetesi operasyonunun kamuoyundaki algılanış biçiminde önemli rol oynayacağını söylemek yanlış olmayacaktır.

Yapılan araştırma çerçevesinde Türkiye'deki medya sektörünün sahiplik yapısının basın kuruluşlarının korku söylemini üretme ve yeniden üretme derecelerini belirlediği ileri sürülebilir. İktidara çok yakın sermaye gruplarının patronajında olan Sabah, Takvim, Star, Akşam, Güneş, Türkiye, Yeni Akit ve Yeni Şafak gazetelerinin Cumhuriyet gazetesiyle ilgili haberlerde kullandığı yazım dili, damgalama, ötekileştirme, düşman ilan etme ve şeytanileştirme için seçilen sözcükler, atılan başlıklar ve haberlerin birinci sayfada işgal ettiği yer açısından diğer gazetelerden çok daha fazla korku söyleminin kurulmasına 
hizmet ettikleri söylenebilir. Doğan Grubu'nun patronajında olan Hürriyet, Ciner Grubu'na ait Habertürk ve Demirören Grubu'nun kontrolündeki Milliyet ve Vatan gazetelerinin korku söyleminin kurulmasında daha az istekli davrandıkları gözlemlenmiştir. Sahiplik yapısı bakımından büyük sermaye grupları arasında yer almayan Sözcü, BirGün, Yurt ve Evrensel gazeteleri operasyona muhalif söylem stratejisi izlemişlerdir. Bu tablonun büyük sermaye gruplarının sahipliğindeki medyanın, Althusser'ci yaklaşımla devletin ideolojik aygıtı olarak işlev gördüğüne ve Gramsci'yi izleyerek egemen sınıfın bir kesiminin diğer kesimleri ikna ederek hegemonyasını inşa etmesine aracılık ettiğine işaret ettiğini söylemek mümkündür.

Politik alana yönelen STY'nin hedefi pratik olduğuna göre, bu makalede yapılan ESA çalışmasının Türkiye'nin güncel siyasal yaşamındaki gelişmelerin açıklanması ve anlamlandırılmasına olan katkısına da değinmek yerinde olacaktır. İktidar, özellikle 15 Temmuz başarısız darbe girişiminin ardından terörist olarak nitelendirdiği birbirinden farklı amacı, çalışma alanı ve tarzı olan örgütlerin tümünü işbirliği içinde gösteren bir korku söylemi stratejisini benimsemiş görünmektedir. Moscovici'yi izleyerek bunun bir komplo zihniyetine işaret ettiğini söyleyebiliriz. Bu stratejinin temel sabiti sözü edilen örgütlenmelerdir. Günün ihtiyacına göre diğer unsur özdeşliğin öbür tarafına yazılabilir. Makale özelinde ülkenin en eski basın kuruluşu olan Cumhuriyet gazetesinin, FETÖ, PKK ve PYD ile özdeşleştirilerek "damgalandığı" gösterilmeye çalışılmıştır. Başka bir konjonktürde Cumhuriyet'in yerine bir sivil toplum kuruluşunun ya da başka bir basın kuruluşunun aynı örgütler üzerinden "damgalanması", "şeytanileştirilmesi" ya da komplonun bir parçası olarak gösterilmesi şaşırtıcı olmayacaktır. Nitekim 16 Nisan 2017'de yapılacak olan anayasa referandumu öncesinde demokratik iki tercihten biri olan "hayır" seçeneğini desteklemek yine iktidar tarafından PKK ve FETÖ tarafında olmakla bir tutulmuştur. Buna bir örnek olarak 6 Şubat 2017'de yayımlanan Sabah gazetesinin manşet haberi gösterilebilir. Gazetenin Başbakan Binali Yıldııı'ın açıklamalarını yansıtan manşeti "IŞTE HAYIR'CILAR PKK- HDP - FETÖ" başlığını taşırken haberin spotunda "Başbakan Yılıııı: PKK, HDP, FETÖ 'hayır' dediği için 'evet' diyoruz. Bu 'hayır' cephesine bakın referandumda öyle kararınızı verin." ifadeleri yer almaktaydı. Keza CHP Genel Başkanı Kemal Kılıçdaroğlu'nun Ankara'dan İstanbul'a yaptığı "Adalet Yürüyüşü" sırasında Cumhurbaşkanı Recep Tayyip Erdoğan, 1 Temmuz 2017 tarihinde yürüyüşe katılanları "FETÖ ihanet çetesine ve onların dümen suyuna girerek ülkesine iftira atanları korumak için yolları arşınlayanlar" olarak nitelendirmiştir. Erdoğan'ın açıklamalarını ertesi günkü sayısında manşetine taşıyan Sabah gazetesi "GiTTiĞiNIZ YOL PENSILVANYA VE KANDIL'IN YOLU" başlığını atmıştır.

Sonuç olarak korku söylemiyle oluşturulan korku kültürünün, iktidarın kitleleri manipüle etmek için korku politikasına başvurmasının zeminini oluşturduğunu söylemek yerinde olacaktır. Korku söyleminin bu şekilde araçsallaştırılması, kuşkusuz medyanın, bizzat sermaye yapısının başka türlüsüne izin vermeyeceği biçimde devletin ideolojik aygıtı olarak işlevine de işaret 
etmektedir. O nedenle çoğulcu demokrasi açısından korku söylemi ve korku kültürünün siyasal izdüşümünü sorunsallaştıran medya ve iletişim çalışmalarına intiyaç her zamankinden daha fazladır. Bu çerçevede yürütülecek çalışmaların çoğunluğun manipüle edilmesinin önüne geçilmesini sağlayacak yöntem ve araçların yaratılmasına katkı sağlayacağı açıktır.

\section{Kaynakça}

Adaklı, G. (2006). Türkiye'de Medya Endüstrisi. Ankara: Ütopya.

Altheide, D.L. ve Michalowski, R. S. (1999). Fear in The News: A Discourse of Control. The Sociological Quarterly, vol. 40, no. 3, 475-503.

Altheide, D.L. (2003). Mass Media, Crime, and The Discourse of Fear. The Hedgehog Review, Fall 03, 9-25.

Altheide, D.L. (2006). Terrorism and the Politics of Fear. Cultural Studies-Critical Methodologies, vol. 6, no. 4, 415-439.

Althusser, L. (1976). Idéologie et appareils idéologiques d'État. L. Althusser, Positions (1964-1975) içinde (67-125). Paris: Les Éditions Social.

Arcan, H. E. (2010). İnsan Hakları ve Medya: ABD Elit Medyasında Türkiye'ye İlişkin Insan Hakları Haberlerinde Söylem İnşası; The New York Times Gazetesi Örneği. Yayınlanmamış doktora tezi, İstanbul Üniversitesi Sosyal Bilimler Enstitüsü.

Aşkın, A.C. (2015). Küresel ve Yerel Dezenformasyon. Ankara: Epos.

Aydın, U.U. (Ed.) (2015). Neoliberal Muhafazakâr Medya. İstanbul: Ayrıntı.

Beck, U. (1992). Risk Society: Towards a New Modernity. New York: SAGE.

Beck, U., Giddens A. ve Lash, S. (1994). Reflexive Modernization: Politics, Tradition and Aesthetics in the Modern Social Order. Oxford: Polity.

Campbell, C. (2013). Günah Keçisi (G. Kastamonulu, Çev.). İstanbul: Ayrıntı.

Carnoy, M. (2001). Gramsci ve Devlet (M.Yetiş, Çev.). Praksis (3), 252-278.

Castells, M. (2009). Communication Power. New York: Oxford University Press. Chomsky, N. (2012). Medya Gerçeği (4. baskı). (A. Yılmaz ve O. Akınhay, Çev.). İstanbul: Everest.

Çiçek, C. (2015). 1 Kasım 2015 Seçimleri ve HDP: Kayıplar, Kazançlar ve Sonuçlar. Birikim. Erişim 8 Ağustos 2017, http://www.birikimdergisi.com/guncelyazilar/7301/1-kasim-2015-secimleri-ve-hdp-kayiplar-kazanclar-ve-sonuclar\#. WYnRAdSLTs0.

Düzgit, S.A. (2014). Critical discourse analysis in analysing European Union foreign policy: Prospects and challenges. Cooperation and Conflict, vol. 49(3), 354-367. 
Entman, R.M. (1993). Framing: Toward Clarification of a Fractured Paradigm. Journal of Communication, vol. 43, no. 4, 51-58.

Erdoğan, I. (2012). Pozitivist Metodoloji ve Ötesi: Araştırma Tasarımları, Niteliksel ve Istatistiksel Yöntemler (3. baskı). Ankara: Erk.

European Commission, Commission Staff Working Document, Turkey 2016 Report.

Fairclough, N. (1989). Language and Power. New York: Longman.

Fairclough, N. (2001). Critical discourse analysis as a method in social scientific research. R. Wodak ve M. Meyer (Ed.) Methods of Critical Discourse Analysis içinde (121-138). Great Britain: SAGE.

Furedi, F. (2014). Korku Kültürü. (B. Yıldııım, Çev.). İstanbul: Ayrıntı.

Girard, R. (1986). The Scapegoat. (Y. Freccero, Çev.). Baltimore: The John Hopkins University Press.

Kaya, A. R. (2009). İktidar Yumağı. Ankara: İmge.

Kerestecioğlu, I. Ö. (2016). Korku ve Siyaset: Türk Sağının Ezberlerini Çözümlemek. i. Ö. Kerestecioğlu ve G. G. Öztan (Der.). Türk Sağı: Mitler, Fetişler, Düşman imgeleri (3. baskı) içinde (29-43). İstanbul: Iletişim.

Kurban, D. ve Sözeri, C. (2012). İktidarın Çarkında Medya: Türkiye'de Medya Bağımsızı̆ğının Önündeki Siyasi, Yasal ve Ekkonomik Engeller. İstanbul: TESEV Yayınları.

Medya İzleme Raporu Temmuz - Eylül 2016. Erişim 29 Kasım 2016, http://www. cgd.org.tr/index. php?Did=591\&Page=1.

MedyaTava Tiraj Tablosu. Erişim 8 Ağustos 2017, http://www.medyatava.com/ tiraj/2016-10-31.

Morgan. E. C. (2004). Collective Political Violence. Great Britain: Routledge.

Moskovici, S. (1987). The Conspiracy Mentality. Erişim 11 Ağustos 2017. https:// www.researchgate.net/publication/279408930_The_Conspiracy_Mentality.

Özkan, A. (2016). 7 Haziran ve 1 Kasım Seçimlerinde Siyasal İletişim. SETA. Erişim 8 Ağustos 2017 http://file.setav.org/Files/Pdf/20160126153913_7-haziran-ve-1kasim-secimlerinde-siyasal-iletisim-pdf.pdf.

Parlak, I. (2015). Yerel Seçimler Ulusal Düşmanlar. SBF Dergisi, c. 70, no.3, 507540.

Parlak, i. ve Uz, P. (2015) Mağdur/Mazlumdan Mağrur/Muktedire 30 Mart Seçimleri. Düşünen Siyaset (Birikimler-II), sayı 30, 69-106.

Reisigl, M. ve Wodak, R. (2001). Discourse and Discrimination. New York: Routledge. 
Taşkale, A. R. (2015). Neoliberal ve Militarist Post-Politika. (M. Serin, Çev.). Ankara: Nota Bene.

Tekin, B. Ç. (2008). The construction of Turkey's possible EU membership in French political discourse. Discourse \& Society, vol. 19(6), 727-763.

Tuchman, G. (1980). Making News: A Study in the Construction of Reality. USA: The Free Press.

Van Dijk, A. T. (1988). News As Discourse. USA: Lawrence Erblaum Associates, Inc., Publisher.

Van Dijk, A. T. (1993). Principles of Critical Discourse Analysis. Discourse\&Society, vol. 4 (2), 249-283.

Wodak, R. (2001a). What CDA is about - a summary of its history, important concepts and its development. R. Wodak ve M. Meyer (Ed.). Methods of Critical Discourse Analysis içinde (1-13). Great Britain: SAGE.

Wodak, R. (2001b). The discourse-historical approach. R. Wodak ve M. Meyer (Ed.) Methods of Critical Discourse Analysis içinde (63-94). Great Britain: SAGE. 